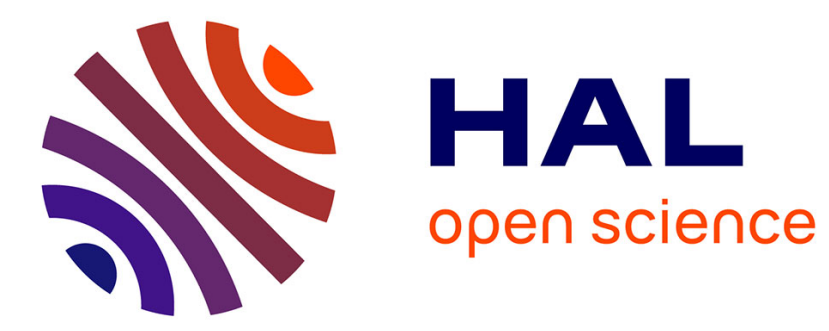

\title{
Catching the local buzz by embedding? Empirical insights on the regional embeddedness of Multinational Enterprises in Germany and the UK
}

\author{
Jan-Philipp Kramer, Javier Revilla-Diez
}

\section{- To cite this version:}

Jan-Philipp Kramer, Javier Revilla-Diez. Catching the local buzz by embedding? Empirical insights on the regional embeddedness of Multinational Enterprises in Germany and the UK. Regional Studies, 2011, pp.1. 10.1080/00343404.2011.571240 . hal-00708537

\section{HAL Id: hal-00708537 \\ https://hal.science/hal-00708537}

Submitted on 15 Jun 2012

HAL is a multi-disciplinary open access archive for the deposit and dissemination of scientific research documents, whether they are published or not. The documents may come from teaching and research institutions in France or abroad, or from public or private research centers.
L'archive ouverte pluridisciplinaire HAL, est destinée au dépôt et à la diffusion de documents scientifiques de niveau recherche, publiés ou non, émanant des établissements d'enseignement et de recherche français ou étrangers, des laboratoires publics ou privés. 


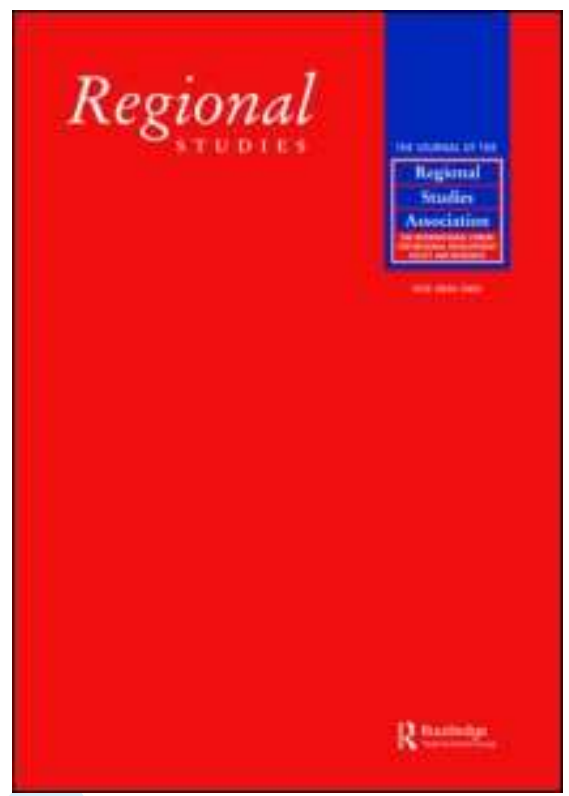

\section{Catching the local buzz by embedding? Empirical insights on the regional embeddedness of Multinational Enterprises in Germany and the UK}

\begin{tabular}{|c|l|}
\hline Journal: & Regional Studies \\
\hline Manuscript ID: & CRES-2009-0353.R2 \\
\hline Manuscript Type: & Special Issue Paper \\
\hline JEL codes: & $\begin{array}{l}\text { R11 - Regional Economic Activity: Growth, Development, and } \\
\text { Changes < R1 - General Regional Economics < R - Urban, Rural, } \\
\text { and Regional Economics, F23 - Multinational Firms |International } \\
\text { Business < F2 - International Factor Movements and International } \\
\text { Business < F - International Economics, O32 - Management of } \\
\text { Technological Innovation and R\&D < O3 - Technological } \\
\text { Change|Research and Development < O - Economic Development, } \\
\text { Technological Change, and Growth, L22 - Firm Organization, Market } \\
\text { Structure: Markets vs. Hierarchies; Vertical Integration < L2 - Firm } \\
\text { Objectives, Organization, and Behavior < L - Industrial Organization }\end{array}$ \\
\hline Keywords: & $\begin{array}{l}\text { Regional Embeddedness, Multinational Enterprises, Intangible } \\
\text { Assets, Regional Innovation Systems }\end{array}$ \\
\hline \hline
\end{tabular}




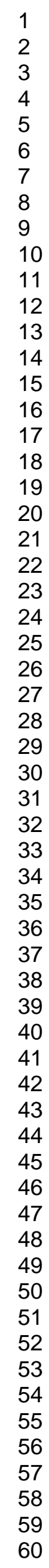

\section{SCHOLARONE ${ }^{m}$ \\ Manuscripts}

7

9

10

11

12

(3)

16

17

18

19

20

22

23

25

26

27

29

30

32

33

34

35

36

39

40

41

42

44

45

46

47

48

50

51

52

53

54

56

57

58

60

http://mc.manuscriptcentral.com/cres Email: regional.studies@fm.ru.nl 


\title{
Catching the local buzz by embedding? Empirical insights on the regional embeddedness of Multinational Enterprises in Germany and the UK
}

\author{
JAN-PHILIPP KRAMER and JAVIER REVILLA DIEZ \\ Institute of Economic and Cultural Geography, Leibniz University Hannover, Schneiderberg 50, \\ 30167 Hannover, Germany \\ E-mail: kramer@wigeo.uni-hannover.de and diez@wigeo.uni-hannover.de
}

(Received February 2010: in revised form March 2011) 


\begin{abstract}
What determines the regional embeddedness of Multinational Enterprises (MNEs) and how do these globally operating firms harness external knowledge which is considered to be "out there" in Regional Innovation Systems (RIS)? Despite the increasing importance of this matter, both from a research and management perspective, there is still an insufficient understanding of the regional embeddedness of MNEs.

By integrating insights from studies on intangible assets, corporate organization of innovation and RIS, this exploratory case study analysis presents a novel matrix of MNE regional embeddedness, using qualitative evidence from 56 in-depth interviews with senior members of leading MNEs from the ICT, automotive and pharmaceutical industries from highly developed RIS in Germany and the UK.
\end{abstract}

\title{
Keywords
}

Regional Embeddedness, Multinational Enterprises, Organization of Innovation, Intangible Assets, Regional Innovation Systems.

\section{JEL Classification}

F23, L14, L22, O31, O32, R11. 


\section{INTRODUCTION}

Recently there has been a growing awareness in the management, international business and economic geography literature that Multinational Enterprises (MNEs) are increasingly using their global network to augment competitive advantages and/or create new advantages by tapping into geographically dispersed sources of knowledge within Regional Innovation Systems (RIS; CANTWELL and IAMMARINO, 2003; REVILLA DIEZ and BERGER, 2005; BOUTELLIER et al., 2008). BASF's biotech center close to Boston, the Hitachi Dublin Laboratory within the campus of Trinity College Dublin, or Nokia's Research Center Palo Alto are good examples of such embedding strategies (COOKE, 2005; BOUTELLIER et al., 2008).

However, whilst research has emphasized that MNEs need to increasingly use their multinational network to access external knowledge and augment intangible assets (IAs), such as localized human capital, $\mathrm{R} \& \mathrm{D}$ processes or partner networks, there is a limited understanding of how MNEs use these often regionally confined competencies strategically (McCANN and MUDAMBI, 2004). Although the regional embeddedness of firms, i.e. the extent and manner in which a firm is integrated into a particular RIS in order to benefit from proximity dynamics has been shown to be advantageous for capturing locational advantages in innovation (REVILLA DIEZ and BERGER, 2005; STEINLE and SCHIELE, 2008; MALECKI, 2010), the underlying processes of how MNEs harness this external knowledge which is considered to be "out there" in RIS is less clear. In other words, what are the relationships between MNEs and their regional environment in terms of the creation of new knowledge and innovation? What determines the regional embeddedness of MNEs in highly developed RIS within advanced, knowledge based 
economies within Europe? How do they embed into regional innovation networks and to what extent is this embeddedness resulting from deliberate strategic actions?

In order to tackle the outlined research gap, this paper uses insights from three bodies of literature: findings on IAs help to identify inputs, processes and structures that sustain firm and regional innovation capacities and that can potentially facilitate the regional embeddedness of MNEs. Research on RIS provides valuable insights as the concept is an appropriate framework to analyze the degree of firm embeddedness. Finally, findings on the corporate organization of innovation processes, embedding strategies and innovation performance outline important determinants affecting the regional embeddedness of MNEs.

\section{REGIONAL INNOVATION SYSTEMS, INTANGIBLE ASSETS AND EMBDEDDNESS}

Evolutionary Dynamics of Regional Innovation Systems and the Role of MNEs

COOKE et al. (2004, p. 3) define a RIS as “[...] interacting knowledge generation and exploitation sub-systems linked to global, national and other regional systems for commercializing new knowledge". Accordingly, a RIS consists of a regional knowledge generation and diffusion (KGD) subsystem (R\&D and higher education institutions etc.); a knowledge application and exploitation (KAE) subsystem (regional networks of firms, suppliers etc.); and a regional policy (RP) subsystem (government bodies etc.) (COOKE, 2002).

Traditionally, concepts on location choices of firms treated regional endowments as external variables, i.e. firms were "thought to view the local labour market, the local innovation system or the general quality of life in a region as given and chose the location that best suits the company's needs" (NUSSMUELLER et al., 2009, p. 2). As this view was challenged by empirical observations, scholars provided arguments to reverse that view and highlighted central motivations for firms to engage in regional upgrading efforts despite implicit externalities. 
Scholars such as STORPER and WALKER (1989), PORTER and STERN (2001) or SCHIELE (2010) argue that firms have an importance stake in the regional innovation capacity and should engage in upgrading their respective location in key areas, for instance, by encouraging public investments and policies that enhance the RIS, involve in industry associations or engage in establishing training programs and new research centers.

Intangible Assets, Firms and Regions

Research on IAs has recently gained in interest, acknowledging the importance of certain nonmaterial factors as drivers for innovation. In accordance with EUSTACE (2000, p. 31), IAs are defined as "all non-material factors that contribute to the performance of firms [...] or that are expected to generate future economic benefits to the entities or individuals that control their deployment." We will focus on (1) firm-specific IAs, defined as assets which can be exploited by the firm as a whole and (2) region-specific IAs, defined as collective assets belonging to a particular set of interconnected firms, R\&D institutions and public authorities within the same region (DI TOMMASO et al., 2004).

(1) Firm-specific IAs: Building on theoretical insights of the market-based view it is argued that firms survive and thrive not only because of some exogenous market size or industry characteristics but because of factors within the firm (HAMEL and PRAHALAD, 1994), these factors being a collection of tangible and intangible assets. Since firm-specific competencies do not necessarily depend on internal resources alone, it is necessary to include assets of a network of firms (HAMEL and PRAHALAD, 1994). These IAs represent the micro-foundations of dynamic capabilities which undergrid the firm's sensing, seizing and reconfiguration capabilities and strongly determine its innovative capacity (TEECE, 2007). ${ }^{1}$ The management literature has commonly identified three IAs: organizational capital, described as the structures that are able to transform individual know-how into a collective advantage for the whole firm; network capital, 
referred to as the knowledge linked to external relationships of the firm or resources that emerge from the external relations with collaborations partners (e.g., lead users); and human capital, i.e. the knowledge, skills and know-how that employees "take with them when they leave at night" (OECD, 2008, p. 11; EDVINSSON and MALONE, 1997; HUGGINS and IZUSHI, 2007).

(2) Region-specific IAs are widely considered to be sources of sustained regional innovation capacity, fostering the ability of actors in a geographical area to develop and exploit existing resources and competencies (OECD, 2008). Mirroring earlier observations which found that localized innovation systems are essentially sub-national phenomena, the RIS concept (COOKE et al., 2004; REVILLA DIEZ and KIESE, 2009) provides an appropriate framework with which to grasp the economic importance of IAs at the sub-national level. Similarly, research insights on localized knowledge accumulation processes (MALMBERG and MASKELL, 1997; FAGGIAN and McCANN, 2006) have pointed out key regional capabilities which reflect the major IAs identified on the micro level: structural and organizational features of the regional knowledge creation processes, intra-regional as well as extra-regional connectivity, and localized human capital (MALMBERG and MASKELL, 1997; FAGGIAN and McCANN, 2006; HUGGINS and IZUSHI, 2007).

\section{Corporate Organization for Innovation, Embeddedness and Innovation Performance}

Shortened product life cycles and the proliferation of global players around the world have set new framework conditions for firm competitiveness in the knowledge economy, increasingly challenging the traditional approach (e.g., vertical integration, home-base exploiting) of North American and European MNEs at the beginning of the $21^{\text {st }}$ (RUGMAN and D'CRUZ, 2003). Research shows that MNEs in several industries today implement more flexible modes of 
organization, characterized by polycentric networks for knowledge creation, and greater strategic independence of subsidiaries (GHOSHAL and NOHRIA, 1997; FORSGREN et al., 2005).

Along with modified organizational structures, MNEs increasingly perceive embeddedness as a strategy to enhance global competitiveness built on integration into specific local contexts offering accumulated knowledge, skills and expertise (COOKE, 2005; MALECKI, 2010). Many studies provide confirmation that innovative activity is highly agglomerated due to technological spillovers (MALMBERG and MASKELL, 1997) and a high degree of MNE embeddedness in RIS promises benefits from positive local externalities and access to a local buzz, i.e. a knowledge and communication ecology created by face-to-face contacts, co-presence and colocation of a variety of stakeholders in a RIS (BATHELT et al., 2004), which cannot be easily reproduced at any location (CANTWELL and IAMMARINO, 2003). Similar concepts in the literature include "untraded interdependencies", which refer to those cumulative causation-prone externalities that "take the form of conventions, informal rules, and habits that coordinate economic actors under conditions of uncertainty" (STORPER, 1997, p. 5) or "neighborhood effects", which refer to the social or institutional arrangements within RIS that develop over time based on the social interaction of actors, and that help to reduce uncertainties while building a basis for shared understanding (MALMBERG and MASKELL, 2006). All in all, the regional accumulation of this tacit knowledge in the local labor market and knowledge networks provides an intangible asset that is hard to grasp for non-local firms outside a RIS, because in order to fully reap the benefits of local buzz, co-location rather than occasional interludes of face-to-face contact is invariably required (STORPER and VENABLES, 2004; BOSCHMA and FRENKEN, 2009). Additionally, contrary to neo-classical thinking on firm embeddedness and innovation, BOSCHMA et al. (2002) propose an inverted U-shape relationship between the embeddedness and innovative performance of firms. ${ }^{2}$ 
FIGURE 1 about here

As figure 1 illustrates, a positive impact of embeddedness on firm performance is expected, determined by lower transaction costs, more trust, new co-operative institutions and other untraded interdependencies (i.e., contrary to neo-classical models). However, after a certain threshold is reached these positive effects can turn negative, especially when the embedded relations become too closely tied and "lock-ins" occur (i.e., contrary to the classical embeddedness model by GRANOVETTER, 1985).

\section{RESEARCH DESIGN AND METHODOLOGY}

Recognizing the need for in-depth analysis at the micro level that help to develop explanations of the regional embeddedness of MNEs (BOSCHMA et al., 2002), an exploratory case study design was chosen. The reasons for selecting this design were manifold: compared to a survey-based approach, the case study method allows for demonstrating context-specific corporate strategies and their evolution over time (PRATT, 2009). Moreover, by applying a multiple case design, it was possible to search for patterns and differences between the analyzed MNEs. Such a picture is further enriched by the great variety of roles of the interviewees, as different types and intensities of relationships with the regional environment can be expected depending on the function within the MNE (e.g., R\&D, Human Resources, Production).

\section{Case Selection Criteria and Data Collection}

In selecting the case study firms, we accounted for sectoral specificities which could influence a) the corporate organization of innovation activities and b) the degree of regional embeddedness of MNEs (e.g., length and intensity of R\&D investments, firm size, regulatory requirement, market maturity). ${ }^{3}$ The data collection was conducted in three steps: (1) selection of three sectors of analysis which represent key knowledge intensive industries within the countries of investigation $^{4}$; (2) purposeful selection of a non-random sample of MNEs; and (3) establishing of 
contact. The interview partners were chosen based on pre-selected criteria (i.e., senior managerial and technical staff; purposive sampling) and recommendations by firm representatives (snowball sampling; BERNARD and RYAN, 2010).

In the final investigation, nine MNEs belonging to the ICT, automotive and pharmaceutical industries (three for each sector) were studied (for six of them we gathered information in both Germany and the UK). The analysis is based on fifty-six digitally recorded semi-structured expert interviews that were conducted from October 2008 to February 2009, each lasting ninety minutes on average. Taken together, the MNEs in the automotive industry account for 392.000 employees worldwide (2007) and a combined R\&D expenditure of $€ 3.9$ billion (2006). The MNEs from the ICT industry employ over 550.000 people worldwide (2007) and account for $€ 5.9$ billion (2006) in R\&D expenditure. Finally, the pharmaceutical MNEs account for 236.800 employees (2006) and have an aggregated R\&D expenditure of $€ 7.2$ billion worldwide (2006). ${ }^{5}$

\section{Structure of the Interview Guides}

Five interview guides were designed: each of the guides covered some general questions, but also more specific questions related to the function of the interviewee in the firm. ${ }^{6}$ The questions were addressed to between two and five employees from different functional areas at headquarter and subsidiary locations. With this setup, we operationalize the idea of OINAS (1997), who suggested that the embeddedness of a firm should best be interpreted as the sum of individual embeddedness of key decision-makers and of the firm as a collective actor in its regional environment.

\section{Framework and Analytical Procedure}

Building upon the prevailing literature, analytical categories were derived to understand how organizational, network and human capital as well as corporate organization at the MNE level can lead to regional embeddedness and mechanisms through which it interacts with the regional 
environment. Figure 2 depicts how the methodological procedure unfolded: after deriving comparison dimensions from the prevailing literature and developing the four quadrants of the matrix, we conducted the case study analysis.

FIGURE 2 about here

The analytical process relied on a careful codification of the interviews. In accordance with the research design, a half-open coding was conducted using codes established from the prevailing literature and empirically-based categories. This process was followed by a systematic examination of all codes, a comparative content and normalized co-occurrence analysis (GARCIA, 2005). Finally, a KWIC (key-words-in-context) analysis was conducted which led to a conversion of all quotes in the transcribed interviews into matrices (BERNARD and RYAN, 2010). A thorough interpretation of the conversion results is necessary to make sense of this numerical data. In order to avoid post hoc rationalization and to ensure construct validity (YIN, 2003) additional written material about the firms and regions was triangulated. All assessment steps were supported by the qualitative data analysis software Atlas.ti.

\section{EMBEDDED MULTINATIONALS? EMPIRICAL INSIGHTS ON THE EMBEDDEDNESS OF MNES IN REGIONAL INNOVATION SYSTEMS}

The Case Study Regions: Key Characteristics of Industry and Innovation

In Germany, six of the nine investigated MNEs locate the majority of their operations in the strong economic regions of the south, particularly in Baden-Württemberg, Munich, and Rhineland-Palatinate. The other three German firms, operating in the automotive and pharmaceutical industries, had their headquarters in the lower Rhine area of North-Rhine Westphalia (NRW), and in the center/south-east of Lower Saxony.

Baden-Württemberg is one of Germany's most prosperous areas, characterized by flagship mechanical engineering firms and a highly developed network of SMEs. The Stuttgart and 
Karlsruhe regions are leading knowledge driven business locations in Germany, accounting for $12.3 \%$ of all employees in industrial research and $12.9 \%$ of all patent applications in Germany (2005); thus reflecting the rather polycentric structure of the state's economy. ${ }^{7}$ The business sector is supported by strong vocational education, excellent universities and specialized research institutes (e.g., in Heidelberg, Karlsruhe or Stuttgart).

Similarly, Munich is one of the leading business and research regions in Europe and the most important business location in Bavaria, characterized by a high density of knowledge-intensive SMEs and MNEs operating in ICT, bio-tech and mechanical engineering. The area accounts for roughly $13 \%$ of all employees in industrial research and $8.6 \%$ of patent applications in Germany $(2005)^{8}$ and is characterized by a high concentration of excellent scientific institutions.

One of the pharmaceutical firms, on the other hand, has located the core of its German units in the lower Rhine area of NRW and - due to a large scale acquisition - also in Berlin, the former being characterized by an advanced industrial structure with core competencies in the health care industries with more than 90,000 employees. ${ }^{9}$ Similarly, Berlin is also an important location for the pharmaceutical industry with well above 10,000 employees, relevant institutions for clinical studies (e.g., Charité) and proximity to government officials. ${ }^{10}$ The selected German automotive MNEs are located in the center and south-east of Lower Saxony, one of the TOP 5 German automotive clusters in terms of employees in knowledge-intensive industries, responsible for 10.6 $\%$ of the patent applications in the industry $(2005)^{11}$, which, however, lies outside of the core automotive regions in southern Germany.

In the UK, the majority of MNEs interviewed have the core of their operations in the Greater South East. This area largely outperforms the rest of the country in terms of economic and productivity growth; it accounts for more than $1 / 3$ of the national $R \& D$ and has the highest concentration of universities and public research institutions. Within this broader region, there are 
several key technological clusters, to which some of the firms interviewed belong, including the electronics and life science clusters in Cambridge and the ICT agglomeration in the Thames Valley. The competitiveness of the Cambridge clusters is largely linked to the presence of the University of Cambridge. The Thames Valley encompasses the M4 corridor of ICT and life science companies. It is characterized by a presence of over 2,000 foreign firms and strong links with the nearby Universities of Reading and Oxford.

The automotive firms interviewed in the UK operate in the traditional cluster centered in the West Midlands and stretching to the North East of England. The West Midlands host 1500 auto firms with approximately 115,000 employees. ${ }^{12}$ The Northwest of the UK is home to 450 automotive firms, 200 of which are major automotive supply chain firms with a workforce of $43,000 .^{13}$

MNE Embeddedness in Regional Knowledge Creation and Innovation Processes - The Embeddedness Matrix

The contribution of this study is to expand the understanding if and how these firms strategically embed themselves into regional knowledge creation and innovation processes. Figure 3 introduces a two-by-two matrix of the regional embeddedness of MNEs. The horizontal dimension of the matrix shows the mode of external knowledge sourcing, displayed on a spectrum from passive to active. The vertical axis shows the level of embedded relationships, ranging from low to high. While the passive mode of external knowledge sourcing is displayed by a rather problem-oriented consultation process for gaining information and knowledge, the active mode is characterized by intense interaction and a higher degree of mutual learning (HAMEL and PRAHALAD, 1994). A low level of embedded relationships depicts more marketbased relationships with arm's-length transactions, while a high level of embedded relationships refers to a network form of economic exchange with relationships through trust and reciprocity 
(BOSCHMA et al., 2002). The matrix was developed based on a deductive analysis and will be described more in detail in table 1.

FIGURE 3 about here

\begin{abstract}
Regional embeddedness, as advocated here, refers to the extent and manner in which a firm is integrated in a particular RIS to benefit from knowledge exchange and learning facilitated by various proximity dynamics, including organizational, cognitive, social, and geographical proximity (HALINEN and TÖRNROSS, 1998; TAYLOR and LEONARD, 2002; BOSCHMA, 2005).
\end{abstract}

TABLE 1 about here

Overview of the Empirical Results

Table 2 summarizes the results from the KWIC analysis on the embeddedness of MNEs in RIS, using the typology of a RIS as introduced in part two of the paper, and provides valuable insights concerning the different degrees of regional embeddedness.

\title{
TABLE 2 about here
}

Overall, we find that two MNEs from the ICT industry are highly embedded in their regional environment and actively source knowledge from regional partners, thus have been classified as facilitators (REIF). Across all industries in this investigation, we find firms applying a scout (RTTS) approach. Among the firms from the automotive industry we found two rather contrasting degrees of regional embeddedness, depicted by the demander (SOSD) and the mediator (RKM) approach. Finally, one MNE from the pharmaceutical industry was showing a hybrid approach to regional embeddedness, primarily characterized by the RTTS and the RKM approach. It is highly important to note that the overall rating in table 2 refers to an in-context 
estimation of the degree of regional embeddedness and it does not stand for the mean of the cells (compare NUSSMUELLER et al., 2009). We now report the empirical results in detail.

\section{(1) Silent Observers and Solution Demanders - Arm's Length Relationships}

In the empirical material gathered during the course of this study, only a very marginal degree of regional embeddedness can be identified for AUTO-A, even at the headquarter location. The KWIC analysis supports this finding, showing low levels of embedded relationships and rather passive modes of external knowledge sourcing in the KGD subsystem (average rating: 1.7), the KAE subsystem (1.6) and the RP subsystem (1.3). Instead, our analysis generated the following picture: once AUTO-A had reduced its internal research capacities by significantly consolidating its strategic research unit - a move primarily driven by cost competition in the industry and a strategic shift within the firm - external sourcing of basic research from universities and research institutes received more attention on the corporate agenda. However, whilst AUTO-A strategically selected a number of university collaboration partners based on their expertise (mostly located in Germany), geographical proximity to partners at its homebase location was not an important selection criterion. The statement of AUTO-A's Product \& Technology Portfolio Manager confirm this finding:

"Ultimately, we have purposefully defined universities which we understand as our core partners: the RWTH Aachen, the University of Karlsruhe, and the University of Dresden. [...] They develop testing methods for us and conduct some basic research. In some cases we also establish own test rig facilities, for example indoor snow test drums, so that we can do quick-tests throughout the year.” (Product \& Technology Portfolio Manager, AUTO-A)

Likewise, no evidence was found for the realization of shared explorative research facilities or a close embeddedness in regional innovation networks, but rather project-specific consultations for problem-solving and the development of testing methods. These collaboration relations are executed in a highly standardized manner according to joint development agreements which are 
monitored by external gate managers in charge of contract execution, acquisition and calls reflecting the solution demander approach applied by AUTO-A. The following statement confirms this view:

"We have, relative to our competitors, a relatively small research and development unit. [...] We concentrate on translating knowledge into new products and technologies, and not necessarily have to build up a basic understanding of the material properties [...] we obviously need the knowledge, but this research is much better located at universities and research institutes." (Product \& Technology Portfolio Manager, AUTO-A)

In summary, arm's length relationships dominate the external collaborations of AUTO-A which are generally more standardize but not closely regionally embedded. However, as highlighted particularly by the HR division, a more systematic use of the regional potential and development of close linkages to education and research institutions (e.g., within its university ambassador program) are viewed as being crucial to secure access to human capital and to support the identification of the newest developments in the scientific community.

\section{(2) Regional Trend and Technology Scouts - Building Loosely Constituent Relationships}

The empirical material provided compelling evidence for this classification across all sectors analyzed in this study. Firms using a scout approach are PHARMA-B and PHARMA-C as well as AUTO-B and ICT-C.

In the case of PHARMA-B, for instance, which consolidated its pre-clinical research activities after a substantial merger with another German pharmaceutical MNE to two headquarter locations, regional trend and technology scouting with bio-tech companies is actively and systematically supported through regular regional partnering events (e.g., programs of lectures, company presentations), enabling them to identify strategic partners directly, such as bio-tech firms, investors and research institutes. Similarly, close interaction with patent exploitation offices - being either privately or university owned - is facilitated in order to detect the strengths 
of universities and other sources of innovation in a more efficient way, as their R\&D Liaison Manager outlines:

"We also try to look fairly systematically to the outside, even in the academic community, for example through patent exploitation agencies or through direct contacts with our key universities. This is a little trickier than it is with SMEs [small and medium enterprises]. In the biotech sector this is simply more established and there are partnering events and there are all sorts of forums and exchanges where knowledge exchange is undertaken systematically." $(\mathrm{R} \& \mathrm{D}$ Liaison Manager, PHARMA-B)

The KWIC analysis supports these findings, with low levels of embedded relationships but quite active modes of external knowledge sourcing in the KGD subsystem (average rating: 2.1), the KAE subsystem (1.8) and the RP subsystem (2.1).

Similar results were found for PHARMA-C, even though its R\&D network configuration shows substantial differences with more decentralized and entrepreneurial R\&D units - a model strategically chosen recently to manage the research portfolio more efficiently by tapping heavily into external knowledge at earlier stages of innovation, as PHARMA-C's Global Science Environment Development Manager confirms:

"The aim was to keep platform technologies together where it made sense, so you would have all of the advantages of being big but at the same time create smaller more entrepreneurial units called «Centers of Excellence for Drug Discovery», which would focus on particular diseases, which would bring clinical and pre-clinical scientists together in a way that normally doesn't happen [...] As a company we are doing more, we do a lot of collaborations and we get involved in a lot of public private partnerships."(SVP Science Environment Development, PHARMA-C)

In order to do so, PHARMA-C developed specialized scouting groups to identify and access promising academic networks and to monitor research findings. For similar reasons, the company established research advisory boards composed of selected senior academics from leading universities within the countries of operation to assure high-level scientific management decisions and validate, for example, clinical study protocols. Finally, a global venture capital unit 
is used as a means of systematically identifying qualified collaboration partners from scientific institutions and intellectual potential from start-up bio-tech firms. Again, the KWIC analysis supports these findings, showing similar patterns as PHARMA-B (scores for KGD: 2.2, KAE: 2.1, RP: 2.5). However, whilst the scout approach is generally very highly valued by the firm, our interviews uncovered substantial differences between the two countries of analysis, with the German subsidiary units being much less involved in collaborative innovation efforts with academic partners or bio-tech firms and focusing solely on standardized contract research in clinical studies. As the German Head of Research \& Development highlights:

"[...] these collaborations are mainly controlled by the headquarters [...] The co-operations that we have are more likely in the context of contract research, e.g., with so-called Contract Research Organizations which help us to conduct these clinical trials." (Head of Research and Development Germany, PHARMA-C)

Evidence of a scout approach was also identified for MNEs from the automotive and ICT industries. In the case of AUTO-B, the KWIC analysis shows active knowledge sourcing with actors from the KGD (average score: 3.0) and the KAE (2.0) as well as a slightly lower engagement with the regional policy subsystem (1.9). More specifically, the technical centers, the firm's key innovation units, are strategically implemented in selected locations offering a rich environment of specialist knowledge from university partners and research institutes (e.g, Cambridge or Aachen) or a strong customer base in key industry clusters (such as the Midlands or Wolfsburg). The German CEO of AUTO-B describes the strategic motivation for this approach as follows:

"Wolfsburg is certainly very customer oriented, and Aachen is more oriented toward [the recruitment of] employees. We have found that it is hard to meet our growth plans here in the engineering sector in Germany solely from our location in Schwaebisch Gmuend. [...] In this context the location in Aachen was very successful, simply because Aachen has a very dominant position in the field of mechanical engineering." (CEO Germany, AUTO-B) 
However, whilst a high degree of regional organizational and network capital, for example, well functioning regional networks and cluster initiatives, is seen as an effective mechanism for accessing and using regionally available potentials, no close embeddedness of the technical centers is realized, as shown by the following statement:

"[...] today we are in globally networked economy and although there are these local clusters which are beneficial and should be promoted, for us it is sufficient to have a representative there who can ensure access to specialist knowledge and resources or ensure that the specialists to come together whenever necessary.” (CEO Germany, AUTO-B)

The analysis thus also uncovered one exception opposing the pattern described, with a considerably tight corporate integration of a number of instrument-driven testing activities as well as many informal meetings and discussions within the regional university network around its headquarter location in the UK.

Finally, in the ICT industry, ICT-C was classified as primarily applying a scout approach, reporting local collaboration relations with surrounding universities at all its development locations in Germany. While these partners are classified as valuable contacts used for typical R\&D efforts in front-end/pre-market innovation projects or as partners for outsourcing innovation (e.g., for circuit processes), no closer regional embeddedness of the corporate innovation laboratories, for example, in the form of structured $\mathrm{PhD}$ programs or shared infrastructure, was reported by the interviewees. Rather, ICT-C's scouting approach is supported by an institutionalized process of academic network capital extension, primarily through the establishment of temporary institutional cross-move programs from the firm's research labs to selected scientific partner institutions and vice versa. As put by the Vice Present of the Concept Engineering Unit:

"All our development sites have local co-operative relationships with neighboring universities. [...] from our Duisburg [location] we have a co- 
operation with the University of Duisburg [...] and with Aachen. Our Munich [headquarter] has also collaborations with the University of Duisburg and also with Bochum, and with Hanover. And with the Technical University Munich and University of Erlangen - so with many different universities. (Vice President of the Concept Engineering Unit, ICT-C)

While this approach allows for synergistic interaction regarding research trends and scientific developments, close geographical proximity and regional embeddedness of its own units was, again, not emphasized as being a highly significant selection criterion - a pattern that the KWIC analysis confirmed, showing an average rating in the KGD subsystem of 2.4 as well as a 1.8 in the KAE and 1.8 in the RP subsystem.

\section{(3) Regional Knowledge Mediator - Collegial Players}

In the case of AUTO-C, characterized by a strong geocentric R\&D network configuration (BOUTELLIER et al., 2008), the empirical investigation showed convincing evidence for a mediator approach with multidimensional relationships in the vicinity of its headquarter location. AUTO-C developed long-term strategic partnerships with a diverse range of regional stakeholders in efforts to support regional talent management and skills formation processes: firstly, the firm institutionalized a long-term collaboration in the form of a dual studies program for human capital supply with a regional university of applied science. Secondly, it established a corporate university at its headquarters not only to secure the life-long learning of its employees and to conduct basic research in fields such as production technologies, but also to coordinate collaboration with a research consortium of regional university partners (e.g., in a shared PhDprogram). AUTO-C's Head of Development and Planning explained it as follows:

"Scientific collaborations are mostly conducted by our research division. [...] our auto university has built a research consortium with the University of Braunschweig, University of Applied Science in Wolfenbuettel and the University of Hanover. [...] 
The regional component is very, very important for us [...] a central goal of these co-operations is ultimately to develop a pool or create a potential to build up resources efficiently - in order to create access to these qualities, which we must secure for our work. (Head of Development \& Planning, AUTO-C)

Thirdly, its human resources unit reported being actively engaged with regional chambers of commerce, particularly by initiating specialized educational programs in fields where demand was expected to grow (such as electro-mechanical engineering). Finally, another example for the mediator approach is AUTO-C's leading role in establishing a regional study and stay program with city and state government officials, a regional talent management and place branding initiative designed to retain university graduates in the regional labor market, as one of our interview partner described:

"[...] you basically have to identify talent during their studies and, ultimately, also bind to your firm. That does not only have to be [AUTO-C]. [...] We have a very good regionalized structure of suppliers. [...] Ultimately, we have a common interest that the young people, when they come out of school or when they come out of college [...] remain here in the region. (Head of Business Unit, AUTO-C)

Moreover, strong network capital of AUTO-C was also found in the field of supplier collaboration and integration. Acknowledging the strategic relevance of selected key suppliers in development and production processes, AUTO-C implemented several programs designed to strengthen supplier competitiveness around its headquarter location, for example by involving them in regional networks.

\section{(4) Regionally Embedded Innovation Facilitator - Embedded Units for Collaborative Research and Knowledge Exchange}

The two firms in our analysis applying a facilitator approach belong to the ICT industry, namely ICT-A and ICT-B. As our empirical material shows, ICT-A is deeply embedded in its regional environments and consciously devised its locational strategy for innovation on the basis of the local availability of a critical mass of innovative players from science and industry. In fact, our 
analysis demonstrated that the availability of regional pools of specialized labor is strongly related to the decentralized $\mathrm{R} \& \mathrm{D}$ network configuration of ICT-A (depicted by a 3.5 average score for the KGD). Moreover, the firm strategically values the advantages of geographical proximity and collective action capability (i.e. regional network capital) as important components of its capacity to produce knowledge in networks and its continuous collaboration capacity. Several illustrative examples help to support these findings: beginning in the late 1980s, ICT-A began to implement campus-based engineering centers (CEC) inside outstanding university campuses worldwide to tap into regional accumulated knowledge and to support mediation from basic research to product development. As in the case of the CEC Karlsruhe, it has institutionalized and made permanent pre-existing collaboration relationships in proximity to the vast intellectual potential of the regional universities and research institutions, as well as throughout the broader technology region containing more than 2000 firms in the IT sector. As described by ICT-A’s Regional Head of R\&D:

\begin{abstract}
"Karlsruhe is just an interesting cluster [...] we have roughly 2.000 companies in the ICT industry. And of course, we know many. And of course, we exchange knowledge with them".

"[...] the Computer Science Research Center is two minutes across the street. The building is the Technology Factory, a start-up incubator. [...] And in just five minutes walking distance is the Faculty of Computer Science. And in the neighboring buildings - also an institute of the Faculty of Computer Science - is the so-called Shared New Field Group in our offices [...] we are in the heart of the scene." (Head of R\&D Karlsruhe, ICT-A)
\end{abstract}

Such embeddedness is expressed by traditional collaboration approaches (e.g., joint $\mathrm{PhD}$ programs), and by more novel approaches (e.g., shared new field groups or living laboratories) all efforts highly valuing ad-hoc face-to-face interaction and persistent human relations in a trustbased atmosphere supported by geographical, cognitive, and social proximity, as confirmed by the Vice President for Regional Affairs: 
"When I'm still in a very vague phase of $R \& D$, an explorative phase, face to face contacts are important. For instance, I might tell you some things while having a cup of coffee which I would not send out in an e-mail or things for which I would not pick up the phone [...] I believe that this tacit knowledge [...] I will more likely reveal in an atmosphere of trust and more spontaneous in a face to face conversation." (Vice President Regional Affairs, ICT-A)

Finally, ICT-A fundamentally changed its HR approaches a few years ago and implemented a decisive regional strategy for talent creation and university relationship management. More precisely, the firm focused its efforts on highly renowned local university partners in software development and process optimization within Baden-Württemberg and also, as the empirical material here shows, with academic partners in its select UK locations.

ICT-B, which has its headquarters in the RIS of Munich, similarly established close links to local universities, research institutions and other innovation partners, supporting regional knowledge creation processes by providing efficient innovation management support, facilitating joint patent applications or supplying seed capital for start-ups. This collaboration with its primary local university partner represents a long-term-oriented partnership, driven by structured human capital development (e.g., lectures, development of new graduate colleges), steering committees for project-specific coordination aspects, and a framework contract model enabling flexible but continuous collaboration projects (reflecting organizational proximity) in a trusting work atmosphere (reflecting social proximity). As in the case of ICT-A, specialized corporate innovation units of ICT-B, such as cooperative computing and communication labs, are integrated within regional knowledge clusters to stimulate joint research and development in close collaboration with its university partners - once more confirming ICT-B's high level of embedded relations and active mode of knowledge sourcing. An interesting example by the Head of Global Innovation Management helps to emphasize this argument: 
"[...] the interaction frequency and intensity decreases with geographical distance, [...] just as an example, we had a conversation with the Karlsruhe Institute of Technology where a very interesting activity on IT services was started. We had exchanged our ideas with our colleagues from Karlsruhe. We then set up a meeting internally with our colleagues from the Corporate Technology unit and wondered whether it made sense to cooperate. In terms of content, no question, but at this early stage, where the services science is still very ill-defined and narrow, where close personal contact is necessary, the location factor Karlsruhe was unfavorable and we developed a collaboration in Munich instead." (Head Global Innovation Management, ICT-B)

The KWIC analysis confirms the patterns described above with high ratings for systematic extrafirm knowledge sourcing and regional university-industry linkages, strong links between continuous collaboration capacity and local provision of training as well as the importance of geographical proximity (KGD rating: 3.2; KAE: 2.8; RP: 3.0).

\section{Hybrid Configurations}

MNEs do not have only one configuration of regional embeddedness (BOUTELLIER et al., 2008), but rather tend to combine different approaches to source knowledge. Some degree of hybrid configuration was indeed found in all of the analyzed firms. However, only in the case of PHARMA-A there was compelling evidence for a real hybrid configuration combining both a scout and a mediator approach (KGD score: 2.3; KAE: 1.8; RP: 3.0). On the one hand, PHAMRA-A actively pools resources with a wide network of regional and non-regional partners belonging to both academia and industry aiming at early stage research for drug discovery, target identification, development of prototypes or in-licensing of substances. As questioned by the European CRO Manager of PHARMA-A's R\&D unit:

Do we want to exploit regional potential? Does it have great benefits? I just have my doubts. I think we just have to think internationally. [...] Although regional proximity can be an advantage, [...] today it is really not so terribly important anymore. With these modern communication options we talk just as well with someone in the U.S. by telephone or video conference. (European CRO Manager, PHARMA-A) 
Another illustrative example of PHARMA-A's academic network capital is a collaborative genome research center located in the vicinity of one of its distributed corporate innovation labs or it active participation in the scientific community (e.g., participation in conferences, scientific publishing). These factors together support the categorization as a scout approach.

On the other hand, PHARMA-A is an active stakeholder in various collaborative relations with public authorities and regional academic institutions, thus displaying a mediator. For example, in a collaborative effort involving several other regional stakeholders from industry and state authorities, PHARMA-A was engaged in establishing a universities of applied sciences or an international school in the vicinity of its major research site, as described by PHARMA-A's Head of Human Resources:

"We cooperate in Biberach, for example, with public institutions; we have established an international school in Ulm, along with several other companies. We financially supported the establishment of a University of Applied Science for Biotechnology [...] we see our responsibility to develop the region, too." (Head of Human Resources, PHARMA-A)

Based on our findings from the empirical analysis, figure 4 summarizes the MNE classification presented above. Similarly to the results presented for the KWIC analysis, the overall rating in figure 4 refers to an in-context classification.

FIGURE 4 about here

\section{CONCLUSIONS}

Considering the insufficient understanding of the regional embeddedness of MNEs in RIS, this paper has investigated the ways in which MNEs strategically use regional competencies. Integrating ideas from research on IAs, corporate organization of innovation, firm embeddedness and RIS, this exploratory case study analysis proposes a novel matrix of MNE regional embeddedness using triangulated evidence from more than fifty in-depth interviews with senior members of leading German and UK MNEs from the ICT, automotive and pharmaceutical 
industries. By and large, our results confirm empirical findings by CANTWELL and IAMMARINO (2003) or COOKE (2005) who find that European firms tend to be embedded in RIS. However, we discover varying levels of embedded relationships and differing modes of knowledge sourcing across the MNEs analyzed. The results presented here rely on a careful analytical procedure, highlighting (I) approaches characterized by arm's length relationships (Demander); (II) loosely constituent relationships with a low levels of embeddedness relationships but active mode of external knowledge sourcing (Scout); (III) close and regionally embedded relationships which, however, display predominantly passive modes of knowledge sourcing (Mediator); (IV) closely embedded, and often even physically integrated innovation units for active knowledge sourcing and collective learning (Facilitator), and, finally, a hybrid configuration.

This paper contributes to the outlined discussion in three distinct ways: firstly, the matrix on regional embeddedness and the classification of the case study firms demonstrate vital characteristics of MNEs' incorporation in RIS as well as the firm-level heterogeneity regarding strategies and capabilities to benefit from external economies within different regional contexts. This reflects varying levels of dynamic capabilities and the firm's endowment with IAs (e.g., network and organizational capital) and provides empirical evidence for TEECE's (2007) concept of dynamic capabilities. This concept indicates that firms have varying sensing, seizing and reconfiguring capacities that allow them to effectively use internal and external resources and the regional environment as a strategic factor to enhance their competitiveness. Secondly, despite the observed variance in the degree of regional embeddedness, we find that all firms acknowledge the increasing importance of a more proactive and systematic integration in (at least) segments of the RIS - a finding much in line with the open innovation literature (CHESBROUGH, 2003) which shows an increasing propensity of firms to built upon and manage portfolios of external 
sources (e.g., regional skills formation). Finally, although addressed rather indirectly, we find that regional IAs such as multilevel governance of associational and stakeholder interests (i.e., strong regional organizational and network capital), a dynamic institutional milieu, a shared vision for the region's development among regional stakeholders can have a substantial influence on the firms' regional embeddedness. A dynamic local buzz in a RIS can enable regional stakeholders to engage in interactive learning that can offer inspiration and variety to enable new combinations of knowledge required to generate innovations. Consequently, in line with LINNEBACH and GÄRTNER (2009) and MALECKI (2010), we argue that the regional embeddedness of MNEs is promoted by a "responsive" regional culture that responds more readily to forms of corporate engagement, the specialized needs of the RIS and allows for developing reciprocal learning processes. In sum, regional embeddedness might be best seen as a dynamic process incorporating both corporate and regional-level determinants (OINAS, 1997; FORSGREN et al., 2005; LINNEBACH and GÄRTNER, 2009).

Table 3 highlights some key management implications of our research findings by abstracting important dimensions of regional embeddedness of MNEs and their strategic drivers.

TABLE 3 about here

To conclude, the research deficits of this paper should be addressed. Since this study was designed to have an explorative character using qualitative evidence suitable for investigating how MNEs embed into RIS, no information about the effectiveness of such approaches can be provided. Similarly, the results cannot be statistically generalized; rather they contribute analytically to a better understanding of the underlying processes of MNE embeddedness in RIS. Making use of this explorative evidence, future research should investigate these topics in a more quantitative way, aiming at testing underlying relationships, performance variables and the effectiveness of the approaches presented. 
Acknowledgements - The research leading to these results has received funding from the European Community's Seventh Framework Program (FP7/2007-2013) under grand agreement $\mathrm{n}^{\circ}$ 216813. The authors would like to thank the interviewees for spending their precious time with us and answering our questions. We also highly want to thank Simona Iammarino and Elisabetta Marinelli for their substantial support as well as Carlos Freire, Daniel Schiller and two anonymous referees for critical and helpful comments on earlier versions of this paper. The usual disclaimer applies.

${ }^{1}$ Dynamic capabilities of firms are defined as the «firm's ability to integrate, build, and reconfigure internal and external competences to address rapidly changing environments» (TEECE et al., 1997, p. 516).

2 Although BOSCHMA's (2005) argument mainly focuses on social proximity, he also shows that this component is not unrelated to the other dimensions of proximity. In fact, cognitive proximity can stimulate interactive learning, organizational proximity is also characterized by strong ties between partners, and geographical proximity is most likely to stimulate social proximity.

3 We selected MNEs among the 1250 firms with the greatest R\&D investments (R\&D Scoreboard 2007) and among the FT 500 (these criteria were relaxed in one case).

${ }^{4}$ We selected the ICT, automotive and pharmaceutical industry as sectors of analysis, e.g. based on their value added (VA) in current prices: in Germany, the ICT industry accounts for $€ 36$ bn in VA (2007), the automotive for $€ 77$ bn and the pharmaceutical industry for $€ 16$ bn (both 2008). In the UK, the ICT has a VA of $€ 37 \mathrm{bn}$, the automotive of $€ 8$ bn and the pharmaceutical industry of $€ 8.5$ bn (all 2008; OECD ANBERD Database 2009). 
${ }^{5}$ Source: R\&D Scoreboard 2007 and Annual Reports.

${ }^{6}$ The semi-structured interview guides are available on request from the authors.

${ }^{7}$ SV-WISSENSCHAFTSSTATISTIK (SV-W, 2007); GERMAN PATENT and TRADEMARK OFFICE (GPTO; 2005).

${ }^{8}$ SV-W (2007); GPTO (2005).

${ }^{9}$ www.gesundheitswirtschaft.nrw.de (last accessed: 05.02.2011).

${ }^{10}$ www.pharmahauptstadtberlin.de (last accessed: 05.02.2011).

${ }^{11}$ GPTO (2005).

${ }^{12}$ ADVANTAGE WEST MIDLANDS (2007).

${ }^{13}$ NORTH EAST DEVELOPMENT AGENCY (2007). 


\section{REFERENCES}

ADVANTAGE WEST MIDLANDS (2007) Automotive Cluster, 3 Year Plan: 2008-11, AWM, Birmingham;

BATHELT H., MALMBERG A. and MASKELL P. (2004) Clusters and knowledge: local buzz, global pipelines and the process of knowledge creation, Progress in Human Geography 28, 31-56;

BERNARD H.R. and RYAN G.W. (2010) Analyzing Qualitative Data: Systematic Approaches, Thousand Oaks, Sage Publications;

BOSCHMA R., LAMBOOY J. and SCHUTJENS V. (2002) Embeddedness and Innovation, in TAYLOR M. and LEONARD S. (Eds) Embedded Enterprise and Social Capital: International Perspectives, pp.19-35. Ashgate, Hampshire;

BOSCHMA R. (2005) Proximity and Innovation: a Critical Assessment, Regional Studies 39, 6174

BOSCHMA R. and FRENKEN K. (2009) Technological relatedness and regional branching, Papers in Evolutionary Economic Geography 0907, Utrecht University, Section of Economic Geography;

BOUTELLIER R., GASSMANN O. and VON ZEDTWITZ M. (2008) Managing Global Innovation: Uncovering the Secrets of Future Competitiveness, Springer, Berlin; BROSTRÖM A., MCKELVEY M.; SANDSTRÖM C. (2009) Investing in Localized Relationships with Universities: What are the Benefits for R\&D Subsidiaries of Multinational Enterprises?, Industry and Innovation 16, 59-78;

CANTWELL J. and IAMMARINO S. (2003) Multinational Corporations and European Regional Systems of Innovation, Routledge, London; 
CHESBROUGH H. (2003) Open Innovation - The New Imperative For Creating and Profiting from Technology, Harvard Business School Press, Boston;

COOKE P. (2002) Regional Innovation Systems: General Findings and Some New Evidence from Biotechnology Clusters, Journal of Technology Transfer 27, 133-145;

COOKE P., HEIDENREICH M. and BRACZYK H.-J. (Eds) (2004) Regional Innovation Systems: the role of governance in a globalized world, Routledge, London;

COOKE P. (2005) Regionally asymmetric knowledge capabilities and open innovation:

Exploring "Globalisation 2" - A new model of industry organization, Research Policy 34, 1128-1149;

DI TOMMASO M., PACI D. and SCHWEITZER S. (2004) Clustering of intangibles, in BIANCHI P. and LABORY S. (Eds) The economic importance of intangible assets, pp. 73102. Ashgate, Aldershot;

EDVINSSON L. and MALONE M. (Eds) (1997) Intellectual capital: realizing your company's true value by finding its hidden brainpower, Harper Business, New York;

EUSTACE C. (2000) The Intangible Economy: Impact and Policy Issues, Report for the European High Level Expert Group on the Intangible Economy;

FAGGIAN A. and McCANN P. (2006) Human Capital and Regional Knowledge Assets: a Simultaneous Equation Model, Oxford Economic Papers 58, 475-500;

FORSGREN M., HOLM U. and JOHANSON J. (2005) Managing the Embedded Multinational: A Business Network View, Edgar Elgar, Cheltenham;

GARCIA E. (2005) Keywords co-occurrence and semantic connectivity. An introductory series on co-occurrence theory for information retrieval students and search engine marketers. Available online at: http://www.miislita.com/semantics/c-index-1.html [Accessed 07 September 2009]; 
GERMAN PATENT AND TRADEMARK OFFICE (2006) Patentatlas Deutschland, DPMA, Munich;

GHOSHAL S. and NOHRIA N. (1997) The Differentiated Network: Organizing Multinational Corporations for Value Creation, Jossey Bass Publishers, San Francisco;

GRANOVETTER M. (1985) Economic action and social structure: the problem of embeddedness, American Journal of Sociology 91, 481-510;

HAMEL G. and PRAHALAD C.K. (1994) Competing for the future, Harvard Business School Press, Boston;

HALINEN A. and TÖRNROOS J.-A. (1998) The role of embeddedness in the evolution of business networks, Scandinavian Journal of Management 14, 187-205;

HUGGINS R. and IZUSHI H. (2007) Competing for Knowledge: Creating, connecting, and growing, Routledge Studies in Global Competition, London;

KOGUT B., WEIJIAN S. and GORDON W. (1993) The Make-or-cooperate decision in the context of an industry network, in NOHRIA N. and ECCLES R.G. (Eds) Networks and organizations, pp. 348-365. Harvard Business School Press, Boston;

LAM A. (2007) Multinationals and transnational social space for learning: knowledge creation and transfer through global R\&D networks, in POLENSKE K.R. (Ed) The Economic Geography of Innovation, pp. 157-189. Cambridge University Press, Cambridge;

LINNENBACH P. and GÄRTNER S. (Eds) (2009) Corporate Culture and Regional Embeddedness - A Multidisciplinary Research Project, Report for the European Commission, Brussels;

MALECKI E.J. (2010) Global knowledge and creativity: New challenges for firms and regions, Regional Studies 44, 1033-1052; 
MALMBERG A. and MASKELL P. (1997) Towards an explanation of industry agglomeration and regional specialization, European Planning Studies 5, 25-41;

MALMBERG A. and MASKELL P. (2006) Localized Learning Revisited, Growth and Change 37, 1-18;

McCANN P. and MUDAMBI R. (2004) The location behaviour of the Multinational Enterprise: Some analytical issues, Growth and Change 35, 491-524;

NORTH EAST DEVELOPMENT AGENCY (2007) Global Winner: Auto Industry Delivers Model Performance, NEDA, Newcastle Upon Tyne;

NUSSMUELLER E., LENGAUER L. and TOEDTLING F. (2009) Motives and influencing factors of corporate regional engagement, Paper presented at the Regional Studies Association International Conference 2009, Leuven;

ORGANISATION FOR ECONOMIC CO-OPERATION AND DEVELOPMENT (2008) Intellectual assets and value creation: Synthesis Report, OECD Publishing, Paris; ORGANISATION FOR ECONOMIC CO-OPERATION AND DEVELOPMENT (2009) ANBERD Database, OECD Directorate for Science, Technology and Industry, Paris; OINAS P. (1997) On the socio-spatial embeddedness of business firms, Erdkunde 51, 23-32; PORTER M.E. and STERN S. (2001) Innovation: Location Matters, MIT Sloan Management Review 42, 27-36;

PRATT M.G. (2009) From the lack of a boilerplate: Tips on writing up (and reviewing) qualitative research, Academy of Management Journal 52, 856-862;

REVILLA DIEZ J. and BERGER M. (2005) The role of multinational corporations in metropolitan innovation systems: empirical evidence from Europe and Southeast Asia, Environment and Planning A 35, 1813-1835; 
REVILLA DIEZ J. and KIESE M. (2009) Regional Innovation Systems, in THRIFT N. and KITCHIN R. (Eds) International Encyclopedia of Human Geography, pp. 246-251. Amsterdam, Elsevier;

RUGMAN A.M. and D'CRUZ J.R. (2003) Multinationals as flagships firms: Regional Business Networks, Oxford University Press, Oxford;

SCHIELE H. (2010) Early supplier integration: the dual role of purchasing in new product development, $R \& D$ Management 40, 138-153;

STEINLE C. and SCHIELE H. (2008) Limits to global sourcing? Strategic consequences of dependency on international suppliers: Cluster theory, resource-based view and case studies, Journal of Purchasing \& Supply Management 14, 3-14;

STIFTERVERBAND FÜR DIE DEUTSCHE WISSENSCHAFT (2007) FuE-Datenreport 2007 Tabellen und Daten: Bericht über die Erhebung 2005, SVW, Essen;

STORPER M. and WALKER R. (1989) The Capitalist Imperative. Territory, Technology, and Industrial Growth, Oxford University Press, New York;

STORPER M. (1997) The Regional World. Territorial Development in a Global Economy, Guilford, New York;

STORPER M. and VENABLES A.J. (2004) Buzz: face-to-face contact and the urban economy, Journal of Economic Geography 4, 351-370;

TAYLOR M. and LEONARD S. (2002) Approaching Embeddedness, in TAYLOR M. and LEONARD S. (Eds) Embedded Enterprise and Social Capital: International Perspectives, pp. 1-18. Ashgate, Hampshire;

TEECE D.J., PISANO G. and SHUEN A. (1997) Dynamic Capabilities and Strategic Management, Strategic Management Journal 18, 509-533; 
TEECE D.J. (2007) Explicating dynamic capabilities: The nature and microfoundations of (sustainable) enterprise performance, Strategic Management Journal 28, 1319-1350;

YIN R. (2003) Case study research: Design and method, Sage, Thousand Oaks.

1

2

3

4

5

6

10

11

12

13

14

15

16

17

18

19

20

21

22

23

24

25

26

27

28

29

30

31

32

33

34

35

36

37

38

39

40

41

42

43

44

45

46

47

48

49

50

51

52

53

54

55

56

57

58

59

60 


\begin{tabular}{|c|c|c|}
\hline $\begin{array}{l}\text { Short } \\
\text { Expression }\end{array}$ & Long Expression & Description \\
\hline Demander & $\begin{array}{l}\text { Silent Observer \& Solution } \\
\text { Demander (SOSD) }\end{array}$ & $\begin{array}{l}\text { Arm's length relationships } \\
\text { - Demander working agenda dominated by development \& process innovation } \\
\text { - Low capacity to value \& exchange knowledge inherent in networks (i.e., low endowment with } \\
\text { network capital) } \\
\text { - Strategically less involved in promotion of collective learning processes } \\
\text { - Collaborations best characterized as discrete exchange relations with limited no. of collaboration } \\
\text { forms = profit-maximizing rationality \& arm's length relationships } \\
\text { - Linkages with external partners more related to applied development work (e.g., focusing on } \\
\text { consultations for problem-solving) } \\
\text { - No active participation in regional initiatives aiming at explorative knowledge creation, no well- } \\
\text { developed links to local scientific personnel \& higher education institutions } \\
\text { - If competence profile of geographically proximate industry or research \& education partners does } \\
\text { not match requirements = no incentive to maintain active relationship }\end{array}$ \\
\hline Scout & $\begin{array}{l}\text { Regional Trend \& } \\
\text { Technology Scout (RTTS) }\end{array}$ & $\begin{array}{l}\text { Building loosely constituent relationships } \\
\text { - Scouts typically located in proximity to places with specialized knowledge \& expertise } \\
\text { - Implemented to tap into new technological developments, business trends \& tacit knowledge } \\
\text { from external stakeholders in various RIS \& transfer insights through internal networks } \\
\text { - Benefit from advantages in coordination of global activities due to skillfully designed } \\
\text { organizational structures = possess high endowment with organizational capital \& greater } \\
\text { capacity to integrate intra- \& extra-firm knowledge networks of globally-spread R\&D units (i.e., } \\
\text { network capital) } \\
\text { - Build only loosely constituent relationships with regional partners, involving a considerably } \\
\text { lower degree of regional embeddedness }\end{array}$ \\
\hline Mediator & $\begin{array}{l}\text { Regional Knowledge } \\
\text { Mediator (RKM) }\end{array}$ & $\begin{array}{l}\text { Collegial players } \\
\text { - Mediators build multidimensional relationships with leading technology suppliers, research } \\
\text { institutes \& customers in region } \\
\text { - Possess high degree of network capital, i.e. core competence is to initiate \& leverage } \\
\text { collaborations with external innovation partners to gain access to new \& complementary } \\
\text { knowledge } \\
\text { - Close, regionally embedded relationships necessary = mediators possess skills \& processes to } \\
\text { build formal \& informal networks within regional environment } \\
\text { - Approach characterized by lower degree of active knowledge sourcing for innovation processes = } \\
\text { units often not closely involved in regional collaborative projects } \\
\text { - Act as "collegial players" (LAM, 2007) seeking to establish long-term strategic partnerships } \\
\text { with a diverse set of regional stakeholders (e.g., in regional skills formation) }\end{array}$ \\
\hline Facilitator & $\begin{array}{l}\text { Regionally Embedded } \\
\text { Innovation Facilitator } \\
\text { (REIF) }\end{array}$ & $\begin{array}{l}\text { Embedded units for collaborative research \& knowledge exchange } \\
\text { - Facilitators closely embed \& often even physically integrate R\&D units into RIS } \\
\text { - Develop continuous multi-dimensional interaction channels with local scientific community, } \\
\text { suppliers, customers = creation of sustained access to regional knowledge reservoirs \& benefits } \\
\text { from localized knowledge spillover } \\
\text { - Strategically promote collective learning within regional innovation networks \& possess } \\
\text { considerable knowledge about who will co-operate \& who has which capabilities (high network } \\
\text { capital endowment) } \\
\text { - Active knowledge sourcing with great intensity \& variety of formal \& informal collaborations } \\
\text { (e.g., staff \& infrastructure sharing agreements with key academic institutions, active } \\
\text { involvement in recruiting \& regional skills formation processes) } \\
\text { - Perceive external networks \& local embeddedness of their R\&D units worldwide as a pivotal } \\
\text { asset of organizational learning and innovation capacity }\end{array}$ \\
\hline
\end{tabular}


Sources: own compilation based on KOGUT et al. (1993); BOSCHMA et al. (2002); LAM (2007); BOUTELLIER et al. (2008); BROSTRÖM et al. (2009)

1

2

3

4

5

6

7

8

9

10

11

12

13

14

15

16

17

18

19

20

21

22

23

24

25

26

27

28

29

30

31

32

33

34

35

36

37

38

39

40

41

42

43

44

45

46

47

48

49

50

51

52

53

54

55

56

57

58

59

60
36

http://mc.manuscriptcentral.com/cres Email: regional.studies@fm.ru.nl 
Table 2. Embeddedness of MNEs in Regional Innovation Systems

\begin{tabular}{|c|c|c|c|c|c|c|c|c|c|}
\hline & $\begin{array}{c}\text { Auto- } \\
\text { A }\end{array}$ & $\begin{array}{c}\text { Auto- } \\
\text { B }\end{array}$ & $\begin{array}{l}\text { Auto- } \\
\text { C }\end{array}$ & $\begin{array}{c}\text { ICT- } \\
\text { A }\end{array}$ & $\begin{array}{l}\text { ICT- } \\
\text { B }\end{array}$ & $\begin{array}{c}\text { ICT- } \\
\text { C }\end{array}$ & $\begin{array}{c}\text { Pharma- } \\
\text { A }\end{array}$ & $\begin{array}{c}\text { Pharma- } \\
\text { B }\end{array}$ & $\begin{array}{c}\text { Pharma- } \\
\text { C }\end{array}$ \\
\hline $\begin{array}{l}\text { Knowledge Generation \& } \\
\text { Diffusion Subsystem } \\
\text { (Research \& Higher Education } \\
\text { Organizations, Innovation Support } \\
\text { Infrastructure) }\end{array}$ & 1.7 & 3.0 & 2.5 & 3.1 & 3.2 & 2.4 & 2.3 & 2.1 & 2.2 \\
\hline $\begin{array}{l}\text { Knowledge Application \& } \\
\text { Exploitation Subsystem } \\
\text { (Contractors, Customers, } \\
\text { Collaborators, Competitors, KIBS) }\end{array}$ & 1.6 & 2.0 & 2.8 & 3.1 & 2.8 & 1.8 & 1.8 & 1.8 & 2.1 \\
\hline $\begin{array}{l}\text { Regional Policy Subsystem } \\
\text { (Policy Institutions, Regional } \\
\text { Development Agencies) }\end{array}$ & 1.3 & 1.9 & 2.6 & 3.0 & 3.0 & 1.8 & 3.0 & 2.1 & 2.5 \\
\hline Overall Rating & $<2$ & 2 & 3 & $>3$ & $>3$ & 2 & $2-3$ & 2 & 2 \\
\hline Classification & SOSD & RTTS & RKM & REIF & REIF & RTTS & Hybrid & RTTS & RTTS \\
\hline
\end{tabular}

Note: we operationalized the embeddedness matrix of MNE regional embeddedness by using a scale ranging from one to four. "One" indicates a low level of embedded relationships and a passive mode of knowledge sourcing (lowest degree of embeddedness; category: SOSD), whereas "four" illustrates the highest level of regional embeddedness (category: REIF). Each quote $\left(Q_{1}-Q_{n}\right)$ of the transcribed and coded interviews was converted into one of these categories. Additionally, for each quote, we indicated whether it referred to one of the following subsystems of a RIS: (1) Knowledge Generation \& Diffusion; (2) Knowledge Application \& Exploitation; (3) Regional Policy. 
Table 3. Regional embeddedness, strategic drivers and competitive advantages

\begin{tabular}{|c|c|}
\hline Regional Embeddedness (Examples) & Strategic Drivers \\
\hline $\begin{array}{l}\text { Engagement in informal innovation networks } \\
\text { (scientific advisory boards, membership in university boards, } \\
\text { lecturing at local universities, temporary cross-moves from } \\
\text { academia to industry) } \\
\text { Engagement in formal innovation networks } \\
\text { (e.g., partnering events, regional cluster initiatives, } \\
\text { networking events, innovation incubators, local chambers, } \\
\text { living labs) }\end{array}$ & $\begin{array}{l}\text { - Access to research institutions and universities } \\
\text { - Identification of potential collaboration partners } \\
\text { - Trend scouting and early identification of new } \\
\text { scientific developments } \\
\text { - Increase of firm absorptive capacity }\end{array}$ \\
\hline $\begin{array}{l}\text { Joint HR initiatives } \\
\text { (schools, higher education institutions and local authorities, } \\
\text { e.g. scholarship, sponsoring, joint PhD-programs, regional } \\
\text { training collaborations, talent retention initiatives, place } \\
\text { branding) }\end{array}$ & $\begin{array}{l}\text { - Secure access to human resources } \\
\text { (including early access to talent) } \\
\text { - Skills formation } \\
\text { - Strategic skills foresight }\end{array}$ \\
\hline $\begin{array}{l}\text { Sophistication of local suppliers, start-ups \& demand } \\
\text { (actively involving suppliers in intra-/extra-regional networks, } \\
\text { development of supplier parks or partner ecosystems, } \\
\text { supplying seed capital through VC units) }\end{array}$ & $\begin{array}{l}\text { - Promotion of supply chain competitiveness } \\
\text { - Customer-/supplier integration } \\
\text { (e.g. for external technology sourcing) } \\
\text { - Learning about new technologies \& business } \\
\text { directions } \\
\text { - Generate new strategic opportunities through } \\
\text { smart investments }\end{array}$ \\
\hline
\end{tabular}




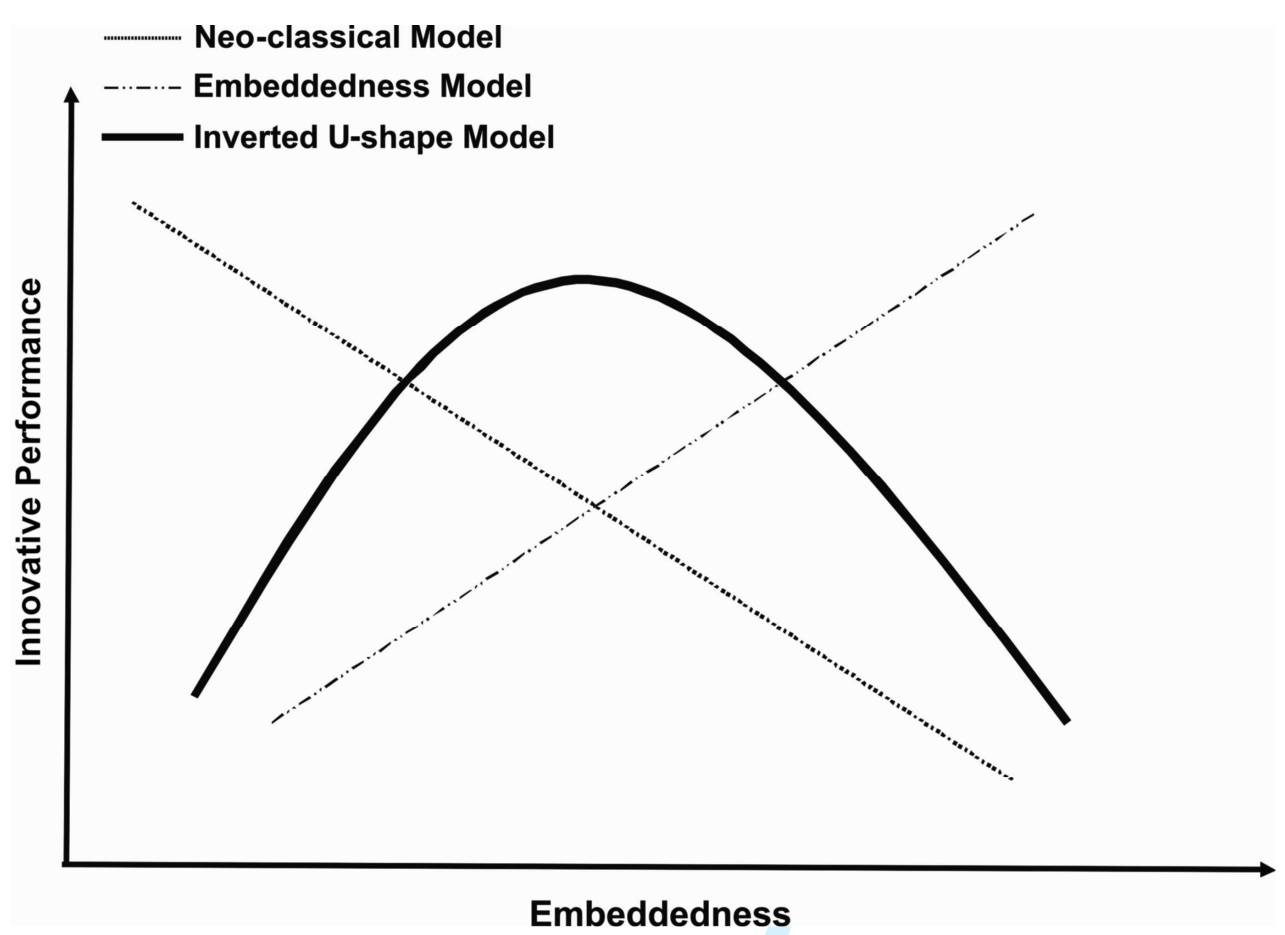

Fig. 1. Relationship between the degree of embeddedness and the innovative performance of a firm Source: Modification of chart in BOSCHMA et al. (2002, p. 31) 


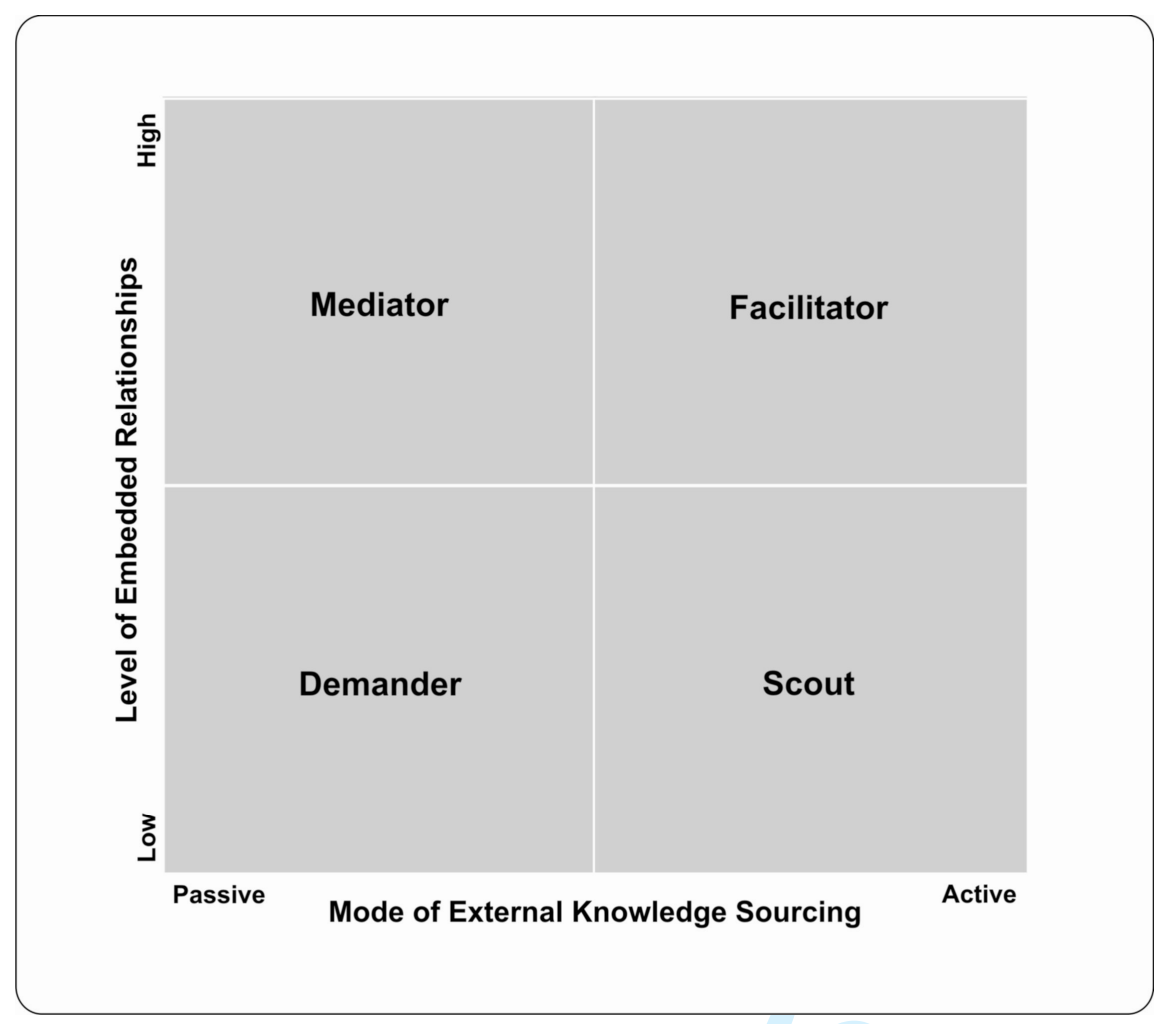

Fig. 3. Regional embeddedness matrix 
